\title{
Fear of the dentist portrayed in cinema
}

\author{
El temor al dentista en el cine
}

\author{
Miguel Alberto Zapata Clavería*
}

Cinema is a very valuable resource to undertake reflections on different aspects of science. For example, bioethics has found in certain medically oriented cinematographic productions a pathway to analyze ethical implications of certain situations that might occur in a given clinical practice. ${ }^{1}$ Meanwhile, Science and Technology Social Studies have focused their attention on films where, in one way or another, science is present; this is undertaken with the aim of understanding beliefs and attitudes exhibited by society towards science. ${ }^{2}$ Communicators, however, target the potential inherent to cinema shows to accessibly transmit to the lay public practical or theoretical aspects of the scientific world. ${ }^{3}$

Dentists have not been overlooked in the seventh art. Dentists have played a starring role in films such as Fleur de cactus, New Jersey smiles, The dentist or Thumbsucker. Other films, although not including dentistry as a central element within the plot, have exhibited memorable scenes taking place in a clinic: Little shop of horrors, Marathon Man or Looking for Nemo. Within the realm of the movies, this representation of dentistry has not gone unnoticed, studies can be found on the image of dentistry projected to the general public. ${ }^{4}$ Moreover, there are projects to show films with oral and dental health subjects to be used for academic and educational projects. The Cinema and Dentists Festival, organized in Spain by the College of Dentists of Navarra, represents a daring bet to offer society a kind image and improve knowledge of the layman on the dental profession. This is achieved through showing films and short films portraying the life of a dentist, typical or parody version of the dental practice, or characteristics of the clinic, techniques and instruments.

Presence of dentistry in the cinema should be considered by the group as an opportunity to analyze the negative image of the profession sustained by part of society. This could be due because, although treated subjects are varied in nature, it cannot be denied that the most frequent one is the fear sustained when having to go to the dentist. The problem lies within the fact that the representation of this aversion in the movies is not only the product of an image that has been progressively building up and imposing, but rather in the fact that it consolidates and prolongs the image.

Some expression of these fears can already be found in classical silent films. In Charles Chaplin's Laffing Gas (Laughing gas) a dentist administers nitrous oxide to a patient in order to sedate him before proceeding with the intervention. This scene carries great historical value, since it shows the 1914 clinical use of $\mathrm{N}_{2} \mathrm{O}$ (produced in 1880 by Humpry Davy). Nevertheless, the most interesting aspect takes place when the dentist exceeds the dosage leaving thus the patient immersed in an uncontrollable laughing fit, situation which forces the brilliant Chaplin, an assistant at the clinic, to hit the patient's head to put an end to his laughing shrieks. Thus, sedation techniques used to avoid pain in surgical practice are revealed as well as an element which causes apprehension due to the suspicion that clinicians lack skill and to the mental construction of negative consequences which can be caused by instrument misuse.

Another fear depicted in the same film is exposure to a subject who does not even have accreditation to exert the profession. In a later scene, the assistant stands in for the dentist, and treats several patients although lacking sufficient knowledge or being entitled to conduct any intervention by himself. In a masterfully comic atmosphere, Chaplin exhibits the mistrust we feel which is caused by the lack of knowledge and professional baggage of a dentist whom we visit for the first time. A similar situation is found in another classic among silent films: Avarice by Erich von Stroheim; in this 1924 feature length film, the main

\footnotetext{
* Professor at the School of Philosophy, National Autonomous University of Mexico (UNAM), Philosophy Graduate and candidate for Philosophy Doctorate Program at the UNAM.
}

This article can be read in its full version in the following page: http://www.medigraphic.com/facultadodontologiaunam 
character opens a clinic without possessing an official degree. The problem of intrusiveness, already serious in any profession, is exacerbated in a practice that very often involves presence of considerable pain and where patient's health and welfare are at risk.

These first representations of dentistry in the movies were followed by other productions where the image of the dentist is established as somebody who creates fear. The dental office becomes a torture chamber, the dentist becomes a psychopath in a white coat whose greater pleasure is the suffering of others, and the patient becomes the victim of prolonged oral torment. In 1960, in The little shop of horrors, by Roger Corman, a disturbed dentist joyfully performs his profession with the sole aim of harming his patients. Only a masochistic character such as that represented by a very young Jack Nicholson could enjoy the pain of others in that alienated practice, where results are a ridiculous edentulous mouth. The next decade, Marathon Man, by John Schlesinger, is shown in the theatres. This film has imprinted in the viewers' memory one of the most recognized scenes of pain inflicted in a dental chair. This time, Dustin Hoffmann endures torture inflicted by Laurence Olivier, who embodies a character based on Doctor Mengele, who was responsible for cruel medical experiments conducted in the Third Reich's concentration camps. The image of a psychopath reaches its paroxysm in 1966 with The Dentist by Brian Yuzna. Without having the quality of the aforementioned films, this picture shows the mental disturbance of a dentist who takes revenge of his wife's infidelity by inflicting pain in the mouth of his patients.

The last three films represent the fear we have to be ignorant of the mental health of a subject who has in his care our mouth, which is such a sensitive and intimate part of our body. The two first pictures mentioned showed the apprehension of not knowing the skills, experience and expert accreditation of the dentist. The fact of acknowledging this type of representations allows the planning of relationship strategies with the patient so as to alleviate his fears. During a first visit, the dentist could reduce mistrust by communicating, in a friendly way, some significant data of his professional or academic experience. In order to dissipate any doubt on his mental health, he could show a communicative, relaxed and friendly attitude.

In summary, an invitation is extended to dentists to acknowledge cultural manifestations where some aspect of their profession makes an appearance, so as to use them to improve their public image. In the case of patients' fears of the repeated projection of the dentists character as an untrustworthy subject, it will enable them to better understand the motives by which many people fear dental consultation, and will thus be in a position to develop strategies to increase trust, decrease fears and improve patient care.

\section{REFERENCES}

1. Casado da Rocha A. El cine en la creación de una ética para la profesión médica: Las normas de la casa de la sidra. Revista Venezolana de Información, Tecnología y Conocimiento. 2009; 6 (2): 13-26.

2. Weingart $P$, Muhl $C$, Pansegrau $P$. Of power maniacs and unethical geniuses: Science and Scientists in Fiction Film. Public Understanding of Science. 2003; 12: 279-287.

3. Moreno ML, Pont JJ. De King Kong a Einstein. La física en la ciencia ficción. Ed. UPC, Barcelona. 1999, p. 332.

4. González PJ. Cine y Odontología. Suspense e intriga en el gabinete dental. Alfred Hitchcock en el 25 aniversario de su fallecimiento. Gaceta Dental: Industria y Profesiones. 2005; 160: 168-173.

Mailing address:

Miguel Alberto Zapata Clavería

E-mail: miguelzapataclaveria@ hotmail.com 